\title{
FILE GOPY
}

U. S. DEPARTMENT OF HEALTH, EDUCATION, AND WETFARE NATIONAL INSTITUTE FOR OCCUPATIONAL SAFETY AND HEALTH CINCINNATI, OHIO 45202

HEALTH HAZARD EVALUATION DETERMTNATION REPORT NO. $73-100-197$

PITTSBURGH PLATE GLASS INDUSTRIES, INC. NEW MARTINSVIITE, WEST VIRGINIA

MAY 1975

It has been determined that employee exposures to caustic mist and mercury vapor were not excessive; however there is a potential for excessive exposure to chlorine gas if approved respiratory protective equipment is not utilized. These determinations are based on the analysis of airborne samples collected in the East and West Chlorine Diaphragm buildings on August 13-14, 1974, observation of the work practices, results of non-directed medical interviews, and toxicological properties of the substances evaluated. Exposure to caustic mist, and chlorine gas may occur by the release of these contaminants into the atmosphere during normal operations, maintenance of the cells or during malfunctions. Exposure to mercury vapor may occur by contamination from the adjacent building which operates mercury cells, however no mercury concentrations were found in the Chlorine Diaphragm Buildings.

Detailed information concerning environmental results are contained in the body of the report.

Copies of this Determination Report are available upon request from the Hazard Evaluation Services Branch, NIOSH, U. S. Post Office Building, Room 508, 5th and Walnut Streets, Cincinnati, Ohio 45202.

Copies have been sent to:

a) PPG Industries, Inc.

b) Authorized Representative of Enployees

c) U. S. Department of Labor - Region III

d) NIOSH - Region III

For the purposes of informing the approximately 8 "affected employees" the employer will promptly "post" the Determination Report in a prominent place(s) near where effected employees work for a period of 30 calendar days. 
Page $2-73-100$

\section{INTRODUCTION}

Section 20 (a) (6) of the Occupational Safety and Health Act of 1970, 29'U. S. Code 669 (a) (6) authorizes the Secretary of Health, Education, and Welfare, following a written request by any employer or authorized representative of employees, to determine whether any substance normally found in the place of employment has potentially toxic effects in such concentrations as used or found.

The National Institute for Occupational Safety and Health (NIOSH) received such a request from an authorized representative of the employees regarding exposures to chlorine gas, caustic mist and a hot environment during the cutting out and replacement of electrolytic cells.

IV HEALTH HAZARD EVALUATION

\section{A. Decription of Process - Conditions of Use}

PPG Industries at this location produces and packages various chemicals. The areas specified in the request for evaluation were the cutting out and electrolytic cell replacement operations in the East and the West Chlorine Diaphragm buildings. Adjacent to these buildings, there is a Mercury Cell building. This area was not included in the evaluation request.

A brine solution is pumped from a subterranean well. This solution is concentrated by distillation. This brine is them pumped into the cells where, by electrolytic decomposition chlorine, hydrogen gas and sodium hydroxide are formed. The replacement of a cell necessitates the removal of ducts and opening of the cell; whereupon the gases and mist may escape from the cells into the work atmosphere. During the above operations, there is a potential for excessive exposure to chlorine gas if respiratory protective equipment was not utilized.

There is no scheduled time for the replacement of cells. The replacement is done when there is a large voltage drop, thereby rendering the cells inefficient. Approximately four (4) cells are replaced in an eight (8) hour work-day. Potential exposure to air contaminants during the replacement cycle would be ten (10) minutes per cell or forty (40) minutes per eight (8)hour work-day. During the remainder of the day employees would perform other duties in an area where exposure to contaminants would be negligible. 
Page $3-73-100$ (Cont')

A. Decription of Process - Conditions of Use

Heat exposure could be à problem during summer months. When the ambient temperature is $900 \mathrm{~F}$ or more the heat is convected from the metal ceiling and since the operation is inherently a heat producer, during hot days some discomfort and heat stress may be experienced. However the operators were noted to spend a minimal time in the building. During the environmental evaluation performed on August 13-14, 1974, no discomfort was experience by the industrial hygienists. The outdoor ambient temperature and humidity were not excessive during this visit.

\section{B. Study Progress and Design}

On September 21, 1973 an initial environmental survey was conducted-at PPG Industries by Al Maier, NIOSH industrial hygienist. A walk-through survey was completed. In addition, a medical questionnaire was completed with employees engaged in cut-out operations. Due to a work stoppage an atmospheric evaluation had to be postponed. Subsequently NIOSH industrial hygienists Walter Chrostek, and William Shoemaker returned to the plant on August 13-14, 1974 to determine air concentrations of chlorine gas, mercury vapor and sodium hydroxide. Informal interviews with the employees were held concerning adverse health affects from exposure to the contaminants at this time.

The plants medical facilities include a dispensary with a full time registered nurse during the day shift. The watchmen are trained in first aid and an ambulance is available. A physician is in the plant a half day per week and is then on call 24 hours per day. They have preplacement and annual physical examinations.

During the initial walk-through survey on September 21, 1973, medical questionnaires were completed with 6 employees in the Chlorine Diaphragm Department. Three of the six $(3 / 6)$ individuals complained of discamfort when exposed to chlorine gas during the cut-out (disconnecting of cells) operation. Five of the $\operatorname{six}(5 / 6)$ individuals complained of fatigue and loss of weight from exposure to heat during the summer months. None (0) reported any symptams resulting from exposure to alkali mist or mercury vapor.

During the visit of August 13-14, 1974 informal interviews were conducted with three (3) employees. They all complained of heat exhaustion on very hot days, however no other symptams were mentioned. 
Page $4-73-100\left(\right.$ Cont $\left.^{\prime}\right)$

C. Evaluation Methods

1) Chlorine Gas

Chlorine gas concentrations in the work atmosphere were determined utilizing MSA $(0.5-20 \mathrm{ppm})$ detector tubes. Breathing zone samples taken during cell replacement and general air samples were taken during malfunctions.

\section{2) Mercury Vapor}

A Bacharach Mercury Sniffer, Model MV 2 was utilized to determine if any mercury contamination occurred from the Mercury Cell building. The areas evaluated were a passageway between the Chlorine Diaphragm and Mercury cell buildings. Especial attention was given to aisleways where tracking of mercury may occur.

\section{3) Alkali Mist}

Exposure to alkali mist was determined utilizing cellulose acetate membranes and personal air sampling pumps. Due to the possible interference of brine, sodium chloride mist, these samples were subsequently chemically analyzed for the sodium and chloride ion.

\section{Evaluation Criteria}

The occupational health standards_promulgated by the U. S. Department of Labor ( Federal Register, June 27, 1974, Title 29, Chapter XVII, Subpart G, Table G-1) 1 and other criteria applicable to the individual substances of this evaluation are as follows:

Substance

Chlorine

Sodium Hydroxide

Mercury (inorganic) 8-hour maximum average exposure

$1 \mathrm{ppm} *$

$2 \mathrm{mg} / \mathrm{M}^{3} * *$

$0.05 \mathrm{mg} / \mathrm{M}^{3} * * *$

* ppm - denotes parts of gas per million parts of contaminated air

** The American Conference of Governmental Industrial Hygienists has adopted this as a ceiling " $C$ " value that should not be exceeded.

*** NIOSH Criteria Document on Inorqanic Mercury, 1973

E. Evaluation Results

1) Chlorine Gas

Utilizing MSA (0.5 - $20 \mathrm{ppm}$ ) length of stain detector tubes, five (5) breathing zone (employees were wearing respirators) samples were taken during the cell replacement cycle. Two (2) general air samples were also taken when a malfunction occurred. Chlorine air 
Page 5 … 7?-100 (Cont')

concentrations during the cell replacement ranged from $0.2-3$ ppm. When a malfunction occurred atmospheric concentrations as high as $10 \mathrm{ppm}$ were measured. The replacement and malfunction repair times were of short duration, however if respiratory protective equipment had not been worn, overexposure to chlorine gas would have occurred.

\section{2) Mercury Vapor}

A. Bacharach Mercury Sniffer, Model MV 2, sensitivity - 0.01 milligram per cubic meter of air, was used to scan the area adjacent to the Chlorine Diaphragm building.

The National Institute for Occupational for Safety and Health has proposed a limit no greater than 0.05 milligram of mercury per cubic meter of air determined as a time weighted average $!$ TWA) exposure for an 8-hour workday. No detectable amounts of mercury were found during this evaluation.

\section{3) Alkali Mist}

The operations evaluated were the cell replacement (cut-out) and cell cleaning. Six samples were collected and analyzed chemically for sodium and chloride ions. If the only air contaminant is presumed to be sodium hydroxide mist, the highest exposure would be $1.08 \mathrm{mg} / \mathrm{M}^{3}$ which is within acceptable criteria. However there is a possibility that brine mist (sodium chloride) may be present. therefore atmospheric concentrations of sodium hydroxide mist may be expected to be lower. In any event no irritation due to exposure to these envirommental contaminants was noted by the industrial hygienists during the evaluation.

\section{F. Discussion Conclusion, and Recammendations}

There appears to be no excessive exposure to mercury vapor or alkali mist. However, there is a potential for exposure to toxic levels of chlorine gas if approved respiratory protective equipment is not utilized. At times, during a cell malfunction general air concentrations can contain as high as $10 \mathrm{ppm}$ of chlorine gas. Patty ${ }^{2}$ reports that at concentrations of 3 to 6 ppm there is stinging or burning sensation in the eyes, nose, throat, and sometimes headache due to irritation of the accessory nasal sinuses. There may be redness and watering of the eyes, sneezing, coughing, and huskiness or loss of voice. Bleeding of the nose may occur and sputum from the pharynx and trachea may be blood-tinged. There is little or no chest pain other than muscular soreness associated with excessive coughing. Imperial Chemical Industries IID, Industrial Hygiene Research Laboratories ${ }^{3}$ report that at concentrations of $10 \mathrm{ppm}$ for 1 minute severe toxic effects can be expected and at concentrations of 4 ppm for more than a short time, may lead to symptams of illness.

NIOSH in their booklet entitled "Working with Chlorine"4 recamends that no one with a history of respiratory illness should be put to work where he could be exposed to even low concentrations of chlorine gas. Those employees working in these areas should be given a complete physical examination before starting to work and at least annually thereafter. 
Page $6-73-100$ (Cont')

Futhermore it is recommended that employees be periodically instructed in the proper use of the approved personal respiratory equipment and in its proper maintenance.

V REFERENCES

1. Federal Register, Vol. 39, No. 125 Part II, Subpart G, June 27, 1974.

2. Patty, Industrial Hygiene and Toxicology Vol. 2, pp 847, July 1967.

3. Imperial Chemical Industries LID, Industrial Hygiene Research Laboratories, iToxic Concentrations of Various Gases, Dissts, Fumes and Metals in the Atmosphere, Second Edition, April 1958.

4. Working with Chlorine. U. S. Dept. of Health, Education and Welfare, PHS, NIOSH, Publication HSM73-11004, 1973.

VI AUTHORSHIP AND ACKNOWLEDGMENTS

Report Prepared By:

Originating office:

\section{Acknowledgments}

Environmental Evaluation:

Laboratory Analysis:
Walter J. Chrostek Industrial Hygienist Region III

Jerome P. Flesch Chief, Hazard Evaluation Services Branch

William E. Shoemaker Regional Program Consultant Region III

A. Wayne Smallwood Chemist, Physical and Chemical Analysis Branch, Division of Laboratories and Criteria Development 
TABLE I

PITTSBURGH PLATIE GLASS INDUSTRIES, INC.

NEW MARTINSVILLE, $W$. VIRGINIA

REPORT NO. 73-100

SODIUM HYDROXIDE MIST

August $13-14,1974$

\begin{tabular}{|c|c|c|c|c|}
\hline Location & $\begin{array}{c}\text { Concentration } \\
\mathrm{mg} / \mathrm{M}^{3}\end{array}$ & $\begin{array}{l}\text { Time } \\
\text { Minutes }\end{array}$ & TWA * * & Remarks \\
\hline \multirow[t]{3}{*}{$\begin{array}{l}\text { Chlorine Diaphragm } \\
\text { building }\end{array}$} & $\begin{array}{l}0.59 \\
0.66\end{array}$ & $\begin{array}{l}197 \\
128\end{array}$ & 0.42 & $\begin{array}{l}\text { Operator's exposure } \\
\text { No. } 2 \text { circuit, } 1-5, \\
\text { cut-out. }\end{array}$ \\
\hline & $\begin{array}{l}1.08 \\
0.15\end{array}$ & $\begin{array}{l}198 \\
163\end{array}$ & 0.49 & $\begin{array}{l}\text { Operator's exposure } \\
\text { No. } 5 \text { circuit, } 1-5 \\
\text { cut-out }\end{array}$ \\
\hline & $\begin{array}{l}0.52 \\
0.74\end{array}$ & $\begin{array}{l}172 \\
176\end{array}$ & 0.43 & $\begin{array}{l}\text { Operator's exposure, } \\
\text { cell cleaning }\end{array}$ \\
\hline
\end{tabular}

* $\mathrm{mg} / \mathrm{M}^{3}$

* * TWA
- milligrams of contaminant per cubic meter of air

- Time Weighted Average exposure for an 8 - hour workday. 
TABLE II

PITTSBURGH PLATE GLASS INDUSTRIES, INC.

NEW MARTINSVIILE, W. VIRGINIA

REPORT NO. 73 - 100

CHIORINE GAS AIR CONCENTRATION DATA

August $13-14,1975$

\begin{tabular}{|c|c|c|c|}
\hline Location & $\begin{array}{l}\text { Concentration } \\
\mathrm{ppm}^{*}\end{array}$ & $\begin{array}{c}\text { Time } \\
\text { (Minutes) }\end{array}$ & Remarkss \\
\hline \multirow[t]{8}{*}{$\begin{array}{l}\text { Chlorine Diaphragm } \\
\text { building } \\
\text { - }\end{array}$} & 0.5 & $2-3$ & $\begin{array}{l}\text { Operator breathing } \\
\text { zone start of cell } \\
\text { bleeding }\end{array}$ \\
\hline & 3 & 3 & As above, during bleeding \\
\hline & 0.2 to 0.5 & 1 & As above, lid lifting \\
\hline & 1 & 2 & As above, gasket scraping \\
\hline & 0.2 & 1 & As above, during draining \\
\hline & 0.75 & 1 & $\begin{array}{l}\text { General air, during draining } \\
\text { and washing }\end{array}$ \\
\hline & $5-10$ & & $\begin{array}{l}\text { General air rear of cell } 58 \text {, } \\
\text { during malfunction }\end{array}$ \\
\hline & 1 & 1 & $\begin{array}{l}\text { General air in aisle } 2 \text { near } \\
\text { cell } 61\end{array}$ \\
\hline
\end{tabular}

*ppm - denotes parts per million parts of contaminated air 